\title{
EXAMEN DE LAS PRINCIPALES FUENTES E INSTITUCIONES ORIGINARIAS DE DERECHO CANÓNICO PLURICONFESIONAL: UNA HISTORIA CRÍTICA PARA LA REVELACION DE FALACIAS Y FUNDAMENTOS
}

[Analysis of the Main Sources and Originary Institutions of the Multiconfessional Canon Law: A Critical History to Reveal Fallacies and Grounds]

\author{
ANTONIO SÁNCHEZ-BAyÓN* \\ Universidad Loyola, Andalucía - Universidad Camilo José Cela, España
}

\begin{abstract}
Resumen
Para poder avanzar hacia un Derecho Canónico Pluriconfesional (o Derecho Eclesiástico Global), integrador de las complejas relaciones entre Ordenamientos cristianos y de estos con los civiles, junto con sus disciplinas correspondientes, resulta necesaria una refundamentación (sin velos de confusión y con sustento en fuentes primeras). En consecuencia, este estudio vuelve a los orígenes, cuando se sientan las bases comunes, que más tarde comenzarán a disgregarse (dando paso a la
\end{abstract}

\begin{abstract}
In order to move forward towards a Multiconfessional Canon Law (or Global Ecclesiastical Law) including the complex relationships between the Christian Regulations and between them and the civilian ones, together with their pertinent disciplines, there should be a new foundation (clear and based on first-hand sources). Consequently, this study returns to the origins, when common grounds, which later started to disperse (giving way to the distinction between Canon
\end{abstract}

RECIBIDO el 3 de julio y ACEPTADo el 16 de diciembre de 2013

* Profesor titular de Universidad en Ciencias Sociales y Jurídicas, calificado por la Agencia Nacional de Evaluación de la Calidad y Acreditación, Prof. Asociado y Coord. Investigación de UCJC, investigador de UNED (Dpto. Historia del Derecho), U. Loyola, LAS-Baylor Univ., ELLSP-DePaul Univ. Dirección postal: calle Galileo, 7, 1 Apto. 11, 28015 Madrid, España. Correo electrónico: antonio_sanchez_bayon@ hotmail.com 
distinción entre el Derecho Canónico y el Eclesiástico protestante, el Derecho Eclesiástico del Estado, el Derecho eclesiástico internacional y comparado, etc.). Se acomete así una revisión crítica, purgadora de falacias, de la Historia iuscanonista pluriconfesional (la realidad pasada en la que se producen los fenómenos y se generan las instituciones), su Historiología (las teorías y métodos con los que se estudia dicho pasado), y su Historiografía (la literatura académica al respecto).

Palabras Clave

Religión-Política-Derecho - Relaciones Iglesia-Estado - Libertad religiosa - Historia - Historiología-Historiografía - Monismo-Dualismo-Pluralismo - Derecho Canónico Pluriconfesional - Derecho Eclesiástico Global.
Law and the protestant Ecclesiastical Law, the State Ecclesiastical Law, the International and compared Ecclesiastical Law, etc.) were established. Thus, a critical revision, to clear away Fallacies of the Multiconfessional Canon Law History (the past where the phenomena take place and institutions are established), its Historiology (the theories and methods with which said past is studied) and Historiography (the related academic literature) are undertaken.

KeYWORDS

Religion - Politics - Law - ChurchState Relationships - Freedom of Religion - History - Historiology-Historiography - Monism-Dualism-Pluralism - Multiconfessional Canon Law - Global Ecclesiastical Law.

\section{Presentación: URgencia Y NeCESIDAd DE REVELACIONES}

Bajo una misma denominación, Derecho Eclesiástico/Canónico, aparentemente se está aludiendo a una misma y rica realidad histórico-social (sobre la ordenación del factor religioso), a un saber científico (con sus teorías y métodos de investigación y sistematización de conocimiento), y a una disciplina universitaria (versada en una rama especial del Ordenamiento estatal, así como en la relación de éste con los ordenamientos religiosos transnacionales, con sus sincretismos posteriores, e.g. regulaciones indígenas y afrocaribeñas, así como otros Ordenamientos internacionales iushumanistas). Además, es necesario aprender a distinguir entre Derecho Eclesial (sinónimo de Derecho Canónico), Derecho Eclesiástico (propio del Protestantismo, cuando los monarcas asumieron competencias sobre el factor religioso, por razón de soberanía, identidad y orden y moral pública), y Derecho Eclesiástico del Estado (expresión generada con la consolidación decimonónica del Estado-nación, que es producto del positivismo formalista de Estado). También existen otras expresiones como Derecho Eclesiástico Comparado (que comprende un estudio más empírico y de interrelaciones entre Ordenamientos vigentes) y el Internacional (que se centra en la cultura democrática y iushumanista de posguerra, donde la religión es fundamental para garantizar estándares 
de conviviencia, a la vez que juega un papel crucial en la geopolítica actual y de su peso sectorial en las organizaciones internacionales). Por todo ello y debido a que estamos en una época de crisis, en la que el Estado-nación llega a su fin, mientras se abre paso la globalización, entonces, se entenderá que este estudio abogue por la expresión holística (armonizadora y de significados añadidos en su visión de conjunto) de Derecho Canónico Pluriconfesional o Derecho Eclesiástico Global: las relaciones entre el poder, lo sagrado y la libertad, o si se prefiere, su concrección en las relaciones derecho-políticareligión. Ahora bien, para lograr fundamentar adecuadamente tal tránsito a un paradigma global, resulta urgente y necesario revisar críticamente los cimientos originarios, no sólo para construir sólidamente, sino también para redescubrir aquel tronco común, que facilite las conexiones y entendimientos actualmente necesarios.

En cuanto a la metodología empleada en este estudio, cabe destacar que: i) sobre sus enfoques, se combina el iuseclesiasticista con el de otras disciplinas de fundamentos, como el iushistoricismo y el iuscomparativismo; $i i$ ) en cuanto a las técnicas, no sólo se han usado las propias del iuseclesiasticismo (donde se combinan las de Derecho y Teología, e.g. exégesis, hermenéutica, heurística), sino que además, para la consecución de la Historia crítica que se prentende, se ha completado el estudio con aquellas técnicas de los enfoques aludidos, más los de comunicación (e.g. análisis de discurso y contenido), pues de lo que se trata es de revelar. Y es que, por "revelación", etimológicamente, se entiende la acción de retirar velos, los cuales entorpecen la percepción y confunden los sentidos, en especial el de la vista, no permitiendo ver más allá o distorsionando lo que hay detrás/debajo. Así, de los muchos velos de confusión que hoy ocultan el Derecho Canónico/Eclesiástico; buena parte de ellos provienen del cientificismo (es la hibridación entre la tecnología y la ideología, para intentar suplantar la ciencia, generándose un pseudo-conocimiento formal inaccesible a los no peritos o especialistas técnico-profesionales), junto con su burbuja cientificista (es la inflación de la denunciada pseudo-ciencia, basada en una producción cortoplacista de consumo y clientelismo). Tales fenómenos posmodernos, de gran presencia e impacto social, y sobre todo universitaria, atacan a las disciplinas de fundamentos y rechazan la tradición, así como, vulneran esferas sociales como la religión. De ahí la urgencia y necesidad de las revelaciones.

Como muestra, sírvase atender a los siguientes ejemplos ilustrativos del deterioro epistemológico, ontológico, axiológico, etc., del Derecho Canónico, y sobre todo del Eclesiástico en España - ergo, afectándose así a las novedosas corrientes latinoamericanas posiblemente influidas-. En muchas universidades españolas, contraviniendo la normativa aún vigente, ni siquiera se enseña ya el Derecho Eclesiástico (en sus diversas disciplinas y asignaturas 
correspondientes) $)^{1}$, y las que sí sobreviven sufren de cierto sesgo cientificista. Llama la atención el caso del manual de la Universidad Nacional de Educación a Distancia ${ }^{2}$, que aunque si bien respeta la denominación oficial, en cambio, confunde cuestiones elementales, al considerar el dualista periodo medieval como monista (véase el capítulo $2^{\circ}$ ). Dada la gran difusión de estos materiales (por el volumen de alumnos de la mencionada Universidad), y el prestigio de la editorial Tirant), se considera más que oportuno este estudio clarificador, de revisión crítica histórica; de ahí que se trate en el siguiente epígrafe de cuestiones tan básicas, y en los siguientes, se esté haciendo referencia continuada a las fuentes originarias.

\section{Propedéutica: Historia, historiología e historiografía DE LA KRATOLOGÍA (MONISMO-DUALISMO-PLURALISMO)}

¿Qué es la Historia, historiología e historiografía del Derecho Eclesiástico Global? Si la Historia se corresponde con la realidad pasada (los hechos y los fundamentos pretéritos), la historiología con las teorías y métodos para el tratamiento de la Historia, y la Historiografía se corresponde con la producción científica sintentizada en tipos ideales epistemológicos de las disciplinas. Entonces, ¿cómo se interpreta la siguiente propuesta expositiva y explicativa relativa al Derecho Eclesiástico y sus cuitas, a medida que ha salido de la ekumene mediterránea y ha llegado a nuevos entornos occidentales como el de las Américas? ¿Y cómo se traduciría todo ello para poder hablar de Derecho Eclesiástico Global? Para poder dar respuesta, antes de entrar en la revisión crítica de las evidencias históricas del periodo fundacional iuseclesiasticista (vid. supra), se procede a ofrecer una serie de aclaraciones preliminares. Entre dichas aclaraciones, una de las más relevantes es la relativa a la denominación Derecho Eclesiástico. Bajo la misma rúbrica se está haciendo referencia a tres acepciones - tal como se viene indicando-, expresivas de los tres niveles de comprensión a recordar en todo momento - para no caer así en las falacias presentes-. A modo de bosquejo de partida -a matizar más adelante-, por Derecho Eclesiástico se entiende ${ }^{3}$ :

${ }^{1}$ Un ejemplo polémico, en este sentido, es el catedrático J.R. Polo, de la Universidad Málaga, quien ha pretendido rebautizar la disciplina como "Libertades Públicas o Derecho y factor religioso". Ha llegado a publicar un manual con la última denominación; véase: Polo, José, Derecho y factor religioso (Madrid, Dykinson, 2012).

${ }^{2}$ VV.AA., Derecho eclesiástico del Estado (Valencia, Tirant lo Blanch, 2012).

${ }^{3}$ Cierto es que tales aclaraciones se extralimitan espacio-temporalmente, pero es la única manera de llamar la atención sobre la disonancia entre la realidad, y sus categorías de estudio, pues existe un riesgo de eurocentrismo no transferible a América tal cual. Incluso dentro del propio eurocentrismo hay errores de base, pues el modelo actual 
a) Como fenómeno y ordenamiento (historia iuseclesiasticista): se alude a la dimensión objetiva del Derecho, esto es, al conjunto de normas coactivas que regulan la dimensión social del factor religioso. Tal Ordenamiento (y más tarde, con el Derecho Eclesiástico del Estado, también un rama del Ordenamiento), que atiende a la especificidad del factor religioso. Tiene su origen en las primeras comunidades cristianas, sufriendo vifurcaciones con los cismas, de donde brotan el Derecho Canónico latino y la veintena de versiones orientales, y el Derecho Eclesiástico (stricto sensu) de los protestantes. Con la Reforma Protestante europea (s. XVI), cuando los gobernantes civiles - pasando a ser estas las nuevas fuentes jurídicas- comienzan a asumir competencias reguladoras sobre la materia por razón de orden social y garantía de la identidad, normatividad y comunicación común, esto es, la justificación del jurisdiccionalismo posibilitador la construcción de las Monarquías modernas y sus Estados-dinásticos -aún no Estados-nación, que son decimonónicos-. Tal noción, muta en las Américas, ya que progresivamente, el Derecho Eclesiástico deja de ser una herramienta de gobierno de las elites para convertirse en el bastión de las bases sociales para exigir un auténtico tránsito a la Modernidad, y por tanto, un real reconocimiento, protección y promoción de la libertad religiosa y del ámbito de autonomía interna del individuo. Evidentemente, esta es la noción eurocéntrica de la materia, que hasta no hace mucho venía excluyendo el reconocimiento de otras visiones americanas, como la indígena y la afroamericana -entre las más destacadas-, de ahí la urgencia de empezar a prestar atención a otros enfoques sobre el poder, lo sagrado y la libertad, así como su visión de relaciones entre las esferas sociales de la religión, la política y el derecho.

b) Como saber jurídico (historiología iuseclesiasticista): se hace referencia a la evolución del pensamiento que dota de sentido a la primera acepción, la del Derecho Eclesiástico como fenómeno y Ordenamiento -y más tarde, como ya se ha indicado, también una rama de Ordenamiento-. Desde las visiones antropológicas occidentales, tras su secularización, las más destacadas corrientes jurídicas (la Iusnaturalista racional, de los siglos XVI-XVIII; la Iushistoricista, siglo XIX; la Iuspositivista, desde el siuglo XIX; vid. punto siguiente), han buscado la tipificación legal de la libertad religiosa como un derecho individual, así como, del principio de autonomía religiosa en las relaciones iglesia-Estado. Sin embargo, no cabe obviar la tardía hermenéutica crítico-cultural, que desde planteamientos -sobre todo- neomarxistas, reivindican una revisión profunda de la concepción positivista formal de

español bebe del italiano, que a su vez es heredero del alemán, y todo ello sin acometerse los procesos necesarios de adaptación idiosincrática. De ahí que con urgencia este estudio busque los fundamentos comunes, los cuales resultan más fáciles de adaptar, sin perder las conexiones con el resto de modelos. 
Occidente. Tales reivindicaciones se fundamentan en las quiebras y exclusiones sociales derivadas de la implantación del pensamiento ilustrado, que ha ido dejando en condiciones de marginalidad a las poblaciones indígenas y afroamericanas (más asioamericanas). Luego, desde dicha corriente críticocultural, se denuncia y exige la observación paritaria de las reglas de juego de los otros americanos, aquellos cuyo pensamiento y antropología subyacente no han sido tenidos en cuenta hasta fechas recientes.

c) Disciplina académica (historiografía iuseclesiasticista): se trata de la fusión y síntesis del estudio de la realidad pasada (el fenómeno social y su rama político-jurídica) y su saber específico aparejado, mediante la construcción de tipos ideales sistematizados y orientados a la enseñanza universitaria, cuya simplicidad bien ayuda al estudiante de Derecho a la compresión por contraste entre modelos, pero que dista considerablemente de la realidad referida. Es por ello que, ya resulta bastante discutible que la fórmula académica centroeuropea decimonónica de Derecho Eclesiástico (en su variante iuspublicista de Derecho Eclesiástico del Estado) se trasplantara adecuadamente al marco mediterráneo a comienzos del s. XX, empero, resultaría sumamente falaz tratar de hacer lo mismo con el marco de las Américas -o cualquier otra área regional de la globalización-. Quizá para ciertos países latinoamericanos sería viable -con bastantes precauciones locales-, pero ello excluiría la posibilidad de atender a las otras antropologías subyacentes (como las ya citadas, indígena y afroamericana). Por otro lado, y desde un punto de vista estrictamente académico, los países angloamericanos, como los Estados Unidos de América y Canadá, vienen estudiando la cuestión desde propuestas de la emergente Sociología Jurídica -ya no tanto centrada en la validez del modelo normativo, sino en la legitimidad y eficacia del mismo, e.g. "Church-State Studies"-. Por tanto, se necesitan enfoques más allá de los tradicionales (e.g. iusnaturalismo, iushistoricismo, iusformalismo), que ha derivado en el paradigma del intercambio desigual a inicios de la globalización, y habría que ir pensando en aquellas propuesta que ayuden a alcanzar y consolidar el nuevo paradigma de la interconexión solidaria -o sea, el (neo) utrumque ius, a través de las organizaciones internacionales- ${ }^{4}$.

Teniendo en mente las prevenciones mencionadas (sobre la Historiahistoriología-historiografía y las acepciones que comprehende el Derecho Eclesiástico), no cuesta deducir que el origen de la confusión actual y el freno al DEG se halla en el caduco y decimonónico positivismo formalista estatalnacional, que negara la juridicidad de otros Ordenamientos que no fueran el propio - ergo, predicando la antijuridicidad de los Derecho Confesionales y

${ }^{4}$ Sánchez-Bayón, Antonio, Sistema de Derecho comparado y global (Valencia, Tirant lo Blanch, 2011). 
el Derecho Internacional, salvo por mediación del Estado-nación-. Y es que el Estado y su legislación son fruto del Derecho y no al revés, tal como se va a probar con las siguientes fuentes seleccionadas para acometer una Historia crítica purgadora de falacias, tal como se viene señalando.

Por tanto, queda por resolver, antes de proceder con las fuentes originarias y sus interpretaciones coetáneas correspondientes, el acometer una breve aclaración sobre la kratología y su significación en Occidente. Como punto de partida, hay que remontarse a las proto-comunidades (entre el fin de la Edad de piedra y el inicio de la Edad de los metales), donde las relaciones entre sus integrantes están aún por definir, sólo rige la fuerza del momento. Sin embargo, allí donde se empieza a tener conciencia de grupo, regido por una serie de reglas comunes reiteradas de convivencia, entonces sí, bajo esas condiciones inicia su emergencia el Derecho: "ubi societas, ibi ius" ("donde hay sociedad, hay derecho"). Por tanto, el poder - más allá de la fuerza bruta- comienza a tomar forma y a manifestarse, resultando tan útil, pues no es necesario tener que convencer constantemente de su observación, sino que es interiorizado como parte de la socialización. Para lograr tal observación, en un principio, las elites recurren a la fe que los hombres depositan en la divinidad, por lo que en ese totum revolutum [amalgama o cajón de sastre] del kratos (poder social), conlleva la unión de Derecho-Política-Religión, bajo la expresión de un Ordenamiento confesional. El Derecho Eclesiástico se corresponde con un estadio más avanzado, donde la secularización ha permitido la discriminación del poder social y sus esferas, dando paso a la emergencia de Derecho Civiles diferenciados. Luego, para comprender cómo acontece tal discriminación, pasándose del Mundo Clásico y su monismo kratológico, desembocándose en el dualismo cristiano medieval, para llegar al pluralismo moderno de libertad, es necesaria una aclaración preliminar más (tal como anuciara el rótulo del epígrafe), sobre la kratología y sus estadios (monismo-dualismo-pluralismo).

La Kratología consiste en el estudio del poder, atendiendo a su fenomenología social, de modo que sea posible percibirlo, interpretarlo y gestionarlo. Durante la Antigüedad, el poder se concibe y se aplica de manera unitaria, a través del miedo: la aceptación del poder confiere una cierta seguridad y su ausencia provoca un profundo temor, considerándose como un presagio de tiempos conflictivos o de catástrofes (e.g. el vacío del poder social precede a las luchas para su conquista, o deja sin contrapeso que se oponga a las fuerzas de la naturaleza). Con la llegada del cristianismo, se abre el camino hacia el Medievo y su dialéctica entre lo terrenal y lo celestial, entre lo temporal y lo eterno, entre la violencia y el amor, etc. Se empieza, de este modo, a distinguir una variedad de expresiones de poder, que entran en colisión mientras se concreta el reparto de las esferas sociales: Religión-Política-Derecho. A diferencia 
de otras religiones de la Antigüedad, el cristianismo no se basa en el miedo (exterior) ni en la seguridad (interior) del grupo, el cual, a su vez, no viene determinado por la geografía (e.g. los griegos), el status socio-económico (e.g. los romanos) o la etnia (e.g. los judíos), sino que tiene una vocación católica -o sea, universal, aunque también oficial, en cuanto entre en contacto con los gobernantes-. En definitiva, el cristianismo ofrece una serie de dualidades conceptuales, que en sus relaciones dialécticas, generan una mayor racionalidad, permitiendo avanzar hacia la tolerancia y la secularización, por lo que poco a poco se va allanando el camino a la libertad del hombre. Ahora bien, pese a que las dualidades parecen fácilmente identificables en teoría (e.g. "dad al César lo que es del César y a Dios lo que es de Dios” (Mt. 22, 15-22; Mc. 12, 13-17; Lc. 20, 20-26), no así transcurren sus tensiones dialécticas en la realidad, donde a veces el poder civil ha procurado imponerse al religioso y viceversa, utilizándose para ello el Derecho, como instrumento para fijar la versión oficial deseada del modelo relacional en cada coyuntura.

\section{MUNDO ANTIGUO Y SUPERACIÓN DEL MONISMO}

A continuación, se procede al estudio histórico-crítico y comunicativo (discursivo) de las fuentes originarias 5 , prestando especial atención a los textos político-jurídicos, pues puede irse comprobando así la paulatina distinción de los propiamente sagrados, además de ser posible la contrastación entre las versiones oficiales que pretenden impulsar y la realidad coyuntural correspondiente.

Los textos elegidos son aquellos que aclaran el proceso de superación del monismo kratológico, pues el dualismo comienza a ser una realidad social, por ende, el poder civil cese su hostigamiento, comenzando a apoyar al episcopado más próximo -intentando, incluso, su asimilación (episcopalidad romana)-. El caso es que, el poder religioso lo acepta con un primer momento -tal injerencia-, pues requiere de una fuerza externa que decante la resolución interna de la primacía de sede apostólica -que no deja de ser una distorsión por influjo del poder político-.

\section{Textos para la tolerancia: edictos imperiales (de la indulgencia a la} catolicidad).

La siguiente selección de textos político-jurídicos arranca con los instrumentos propios de la máxima figura de poder de la Antigüedad tardía: el emperador romano o pontifex-maximus/sacerdos-imperator, pues ha

\footnotetext{
${ }^{5}$ Se trata de traducciones propias elaboradas y aplicadas en las clases del autor tanto en la UCM como en la UEM y en la UCJC; véase la nota 1.
} 
logrado reunir bajo su manto de imperium (auctoritas et potestas) ${ }^{6}$ todas las expresiones de poder social conocidas, de ahí el recelo inicial frente al cristianismo y su dualismo ${ }^{7}$ - por cierto, sírvase a tener en consideración que es el poder proto-civil el que pretende asumir el conjunto del totum revolutum, como se verá más abajo-. Dicha tensión dura hasta descubrir que resulta más conveniente incorporarlo a su seno, que combatirlo para excluirlo. A lo largo del siglo IV, se procede a una inversión de relaciones según una política de tres pasos: $i$ ) indulgencia, $i i$ ) tolerancia, $i i i)$ oficialidad. Se pasa de la persecución a su instrumentalización para mantener vivo el Imperium/ res publica, durante un siglo más en Occidente, y un milenio en Oriente o Bizancio. Como se comprobará entonces, ni la tolerancia ni el cesaropapismo comienza con Constantino -desmontándose así otras falacias históricas conexas, vid. Supra-, ni el cristianismo se hizo con el Imperio (en el sentido de país) -sino al revés-.

a) Edicto imperial de indulgencia ("Edictum indulgentiae", en Nicomedia, año 311, por el emperador Galerio): "[...] Entrelas otras disposiciones que tomamos para uso y beneficio de la comunidad polítical Imperio, ha sido siempre nuestro deseo de que todas las cosas sean constituidas según las leyes antiguas y el orden público romano tradicional. También buscamos que, incluso los cristianos, que habian abandonado la religión de los ancestros, volviesen en razón y al buen sentido/sentido común. En efecto, por algún motivo, la voluntad de los cristianos se nubló y resultó presa de tal locura, que les movió a abandonar las instituciones ancestrales establecidas por sus antepasados. En su lugar, por su propio capricho y como bien les pareció, adoptaron y siguieron leyes propias, congregándose en multitud de grupos separados en lugares diversos. Así, cuando pusimos en vigor nuestras leyes [de represión] con la finalidad de que regresaran a las instituciones tradicionales, algunos se sometieron por el miedo, otros fueron incluso abatidos. Asi, aunque la mayoría perseveró en su locura, nosotros nos dimos cuenta de que ya ni reverenciaban a los dioses de la religión debida ni honraban al dios cristiano, por lo que habida cuenta de nuestra gran clemencia e invetera-

${ }^{6}$ Cicerón: "cum potestas in populo auctoritas in senatu sint". Debido a la devaluación institucional de la República acometida por Octavio Augusto -aunque preparada por César, quien no pudiera disfrutarlo-, comienza así la trampa discursiva del imperium, como poder pleno de la máxima magistratura que aúna auctoritas y potestas en el Principes, que en Occidente será Pontifex-maximus, y en Oriente/Bizancio será Rex-sacerdos -noción que inspirará a Lutero y su fórmula para el gobernante civil de membrum principale ecclesiae-. Todo ello servirá de munición para las tensiones entre el poder religioso/espiritual/eterno y el civil/terrenal/temporal; véase punto siguiente.

${ }^{7}$ Con la crisis imperial del siglo III, se abre el persecucionismo contra los cristianos, inaugurándose con Decio y su Decreto "supplicatio" (para la unificación del culto en súplica a los dioses para salvar el dominium/res publica-mal traducido como Imperio-). 
da costumbre de indulgencia que ejercitamos frente a todos los súbditos, creemos que debemos extenderla también a este caso: que [de nuevo] vivan los cristianos y que puedan reconstituirse, asi como sus lugares de culto, siempre que no vayan contra del orden público. Por medio de otro despacho indicaremos a los magistrados cómo deben conducirse. Por consiguiente, conforme a nuestra indulgencia, deberán orar a su dios por nuestra salud y la del Imperio y la suya propia, para asegurar el bienestar general y para que puedan vivir seguros en sus hogares. Este edicto se dicta en Nicomedia a un día de las kalendas de mayo en nuestro octavo mandato y en el segundo de Máximo Lactantius".

b) Edicto imperial de tolerancia ("Edictum rescriptum mediolanense", en Milán, año 313, por el emperador Constantino): "Nos, los Emperador es Constantino y Licinio, habiéndonos reunido felizmente en Milán, y puesto en orden las cosas que pertenecen al bien común y a la seguridad pública, juzgamos que, entre las cosas que han de beneficiar a todos los hombres, o que deben ser primero solucionadas, una de ellas es la observancia de la religión. Debemos, por consiguiente, dar tanto a los cristianos como todos los otros súbditos, libre oportunidad para profesar la religión que cada uno desee, de manera que, cualquiera que sea la divinidad celestial, pueda ser benigna y propicia con nosotros y con todos los que han sido puestos bajo nuestra autoridad. Por tanto, pensamos que la siguiente decisión es conforme a una sana y verdadera razón: que nadie que haya aceptado la religión cristiana o cualquier otra que parezca ser la más conveniente para sí, sea obligado a negar su convicción, para que de este modo la Suprema Divinidad, cuyo culto es observado libremente pueda asistirnos en todas las cosas con su favor y benevolencia [...] [magistrados] habéis de considerar como vuestro deber restituir los bienes a los cristianos de manera inmediata y sin demora alguna [...] se ha de tener en cuenta que los que observen nuestra declaración anterior, devolviendo los bienes sin poner precio, pueden esperar alguna compensación de nuestra benevolencia. Debéis mostrar suma diligencia en este asunto tocante al cuerpo cristiano, para que nuestro edicto se lleve a la práctica con suma celeridad [...]".

c) Constitución imperial católica ("Codicen Theodosianum, Librum XVI”, en Tesalónica, año 380, por el emperador Teodosio): "[...] Es nuestra voluntad que todos los pueblos que son gobernados por la administración de nuestra clemencia profesen la religión que el divino apóstol Pedro dió a los romanos, que hasta hoy se ha predicado como la predicó él mismo, y que es evidente que profesa el pontifice Dámaso y Pedro, el obispo de Alejandria, hombre de santidad apostólica. Esto es, según la disciplina apostólica y la doctrina evangélica creemos en la divinidad única del Padre, del Hijo y del Espiritu Santo bajo el concepto de igual majestad y de la piadosa 
Trinidad. Ordenamos que los que sigan esta regla sean llamados cristianos católicos. Los demás, empero, a los cualesjuzgamos estar dementes y enajenados, pesará sobre ellos la infamia de la herejia. Sus lugares de reunión no recibirán el nombre de iglesias y serán objeto, primero de la venganza divina, y después serán castigados por nuestra propia iniciativa que adoptaremos siguiendo la voluntad celestial/juicio divino. Dado el tercer día de laskalendas de marzo en Tesalónica, en el quinto mandato de Graciano Augusto y primero de Teodosio Augusto".

2. Textos para la primacía: epistolas episcopales y rescriptios imperiales (confirmación del primado, pero no plenitudo potestas).

En el tránsito de la tolerancia tradicional a la moderna, ésta ya no se concibe restringida y negativamente, como el hecho de soportar el mal ajeno, sino que pasa a recibir un significado más amplio y positivo, como la búsqueda de un término justo, de una equidad vital. Es por ello que, para que llegue a arraigar la tolerancia moderna, se evidencia la necesidad de que coexistan dos poderes paritarios, que sirvan de contrapeso en la marcha social de Occidente: $i$ ) de un lado, el poder civil/terrenal/temporal, en manos del Emperador, indiscutible por su potestas; $i i$ ) de otro lado, el poder religioso/ espiritual/eterno, que de entre los diversos obispos, terminará siendo el papa o "Primado de Roma"-por su auctoritas y como ejemplo de fusión de la tradición sagrada y profana occidental-. La estrategia que se inaugura es la del mutuo auxilio en la legitimación de sus dominios sociales, el problema es que ambos los ejercen sobre una misma comunidad, la cristiandad (Christianitas o Res Publica Gentium Christianorum) -con lo que a la postre surge un choque de vanidades por el mando superior: "unum corpus, unum caput, non duo capita, quasi monstrum" ("un cuerpo, una cabeza, no dos pues sería un monstruo")-. En principio, al haberse inaugurado ya el periodo cesaropapista (tal como se aclara en los siguientes textos), la ventaja del emperador le permite decidir y posicionarse ante un conflicto interno de la Iglesia, procediendo a apoyar de manera tasada al Primado de Roma -o sea, el papa frente al resto de obispos-, esperando sacar el mismo rédito que sus predecesores al instrumentalizar el cristianismo, pero pronto se podrá constatar que la doctrina del "Primado de Roma" no sólo se aplica a los obispos, sino que pretende

\footnotetext{
${ }^{8}$ Se hace referencia a dos principios: $i$ ) properpotentiorem principalitatem (Adversus haereses, año 190 aprox.); ii) non est potestas nisi a Deo (Concilio de Sárdica, año 343). De este modo, se exige que las decisiones de los príncipes también queden sujetas al orden moral, en el que todos los hombres son igualmente responsables, por lo que las decisiones se someten a la autoridad papa l. Más tarde, se extiende dicho principio al poder del papa de ungir al Emperador -por lo que se entiende que éste no lo es por linaje sino por la mediación del papa con Dios-. Supuestamente, la base de dichos
} 
alcanzar a los príncipes terrenales, dando paso al hierocratismo (sembrado por el papa Gelasio y su doctrina: dualismo gelasiano)-.

a) Epístola sobre el primado de Roma ("Adversus haereses", en Lión, año 190 aprox., por el obispo Ireneo): "[...] pero como seria muy largo, en un volumen como este, enumerar las sucesiones de todas las iglesias, nos limitaremos a la Iglesia más grande, más antigua y mejor conocida a todos, fundada y establecida por en Roma por los dos gloriorosisimos apóstoles Pedro y Pablo, demostrando que la tradición que tiene recibida de los Apóstoles y la fe que ha anunciado a los hombres han llegado hasta nosotros por sucesión de obispos. Ello servirá para confundir a los que de una forma u otra, ya sea por satisfacción propia o por vanagloria, ya sea por ceguedad o por equivocación, celebran reuniones no autorizadas. Porque, a causa de su primado de origen superior es preciso que concuerden con esta Iglesia todas las iglesias, es decir, los fieles que están en todas partes, ya que en ella se ha conservado siempre la tradición apostólica por los fieles que están en todas partes [...]".

b) Rescripto imperial de confirmación del papa Siricio frente al cisma (en Milán, año 385, por el emperador Valentino II): "Salud, queridisimo Piniano. El hecho de que el pueblo de la Ciudad Eterna experimente alegría en la concordia al elegir a tan excelente sacerdote, Nosotros vemos que responde a una disposición del pueblo romano y nos alegramos de que haya sucedido asi en nuestros tiempos. Por ello, en la medida en que ellos no sólo han expresado sus deseos de que el religioso y santo obispo Siricio esté al frente del clero, sin que también con sus aclaraciones han reprobado como malvado a Ursino, que el citado obispo, queridísimo y apreciado Piniano, permanezca en el cargo con nuestra alegría. En efecto, es prueba magnifica de su integridad e inocencia el que con una misma aclamación el uno sea aceptado y los demás reprobados. Dictado en Milán a seis días de las kalendas de marzo".

c) Rescripto imperial en caso de ser elegidos dos papas (en Rávena, año 420, por el emperador Honorio): “[...] por todo ello, deseamos que por intermedio de Tu Santidad se haga saber a todos los clérigos que si, por humano imprevisto, cosa que no deseamos, sucediese algo a Tu Religiosidad, deben todos

principios se halla en la Epistola de San Pablo a los Romanos (XIII,1,6) "Estad todos sometidos a las autoridades superiores. Pues no hay autoridad que no venga de Dios, y las que hay, por Dios han sido establecidas. Así pues, quien se enfrenta a la autoridad, se enfrenta al orden establecido por Dios. Y quienes se enfrentan a ella atraen para sí su propia condena [...] porque los poderes administradores no son de temer para los que obran bien, sino para los que obran mal ¿Quieres vivir sin temor a la autoridad? Haz el bien y tendrás su aprobación, porque es ministro de Dios para el bien, pero si haces el mal, teme, que no en vano lleva la espada. Es ministro de Dios, vengador para castigo del que obra mal". Finalmente, en IV Concilio de Letrán (Roma, Inocencio III, siglo XIII), se reconocen una serie de títulos para el Papa, siendo definido como "vicarius Dei” (vicario de Dios), "vicarius Christi” (vicario de Cristo) y "sucesor de San Pedro". 
olvidarse de sus integras. Y si se diese el caso de que fuesen ordenados dos como consecuencia de las luchas entre candidatos rivales, con toda seguridad ninguno de los dos será obispo, sino que sólo se sentirá en la Sede Apostólica aquél que sea elegido clérigo por disposición divina mediante una nueva ordenación hecha con el consenso de todos. Asi pues, ésta es la conducta a seguir, que todos, de acuerdo con las advertencias de Nuestra Serenidad, mantengan un estado de ánimo tranquilo y un espiritu pacifico y que no intenten nada mediante conspiraciones sediciosas sabiendo que no van a servir de nada las posturas faccionalistas/partidistas [...]".

d) Carta de León Magno sobre la consulta de obispos a Roma (del papa a los obispos de la provincia Gala de Vienne, año 445): "Bajo la inspiración de Dios, nosotros nos esforzamos en corregir los abusos tras madura deliberación [...]. Compartiendo en todo esta tarea con vosotros, nos esforzamos por poner orden en vuestras Iglesias, no con la introducción de cosas nuevas sino renovando las cosas antiguas con el fin de preservar en las costumbres que han transmitido nuestros padres y para que, desechando los escándalos del desorden, agradecemos a nuestro Dios en el misterio de una obra buena. Vuestra fraternidad reconoce con nosotros que los obispos, incluidos aquellos de vuestra provincia, han elevado numerosas consultas a la Sede Apostólica llevados de su reverencia hacia ella. Y en los numerosos temas que le han sido planteados, hay decisiones que han sido, o bien abrogadas o bien confirmadas, tal como exige una vieja costumbre. De este modo, habiendo preservado la unidad de espiritu en el lazo de la paz mediante el envío y el recibo de cartas, lo que de una manera santa ha sido hecho ha dado lugar a una caridad duradera. En efecto, nuestra solicitud, que no busca sus propios intereses sino los de Cristo, ni quita ni a las Iglesias ni a los obispos de las Iglesias nada de la dignidad que les ha sido concedida por Dios".

e) Constitución imperial de Valentino III (pronunciamiento respaldando al papa León Magno frente a las pretensiones del Obispo Hilario de Arles sobre su supuesta primacía en el episcopado de la Galia): "[...] Estamos convencidos de que la única defensa para nosotros y para nuestro Imperio es el favor del Dios de los cielos; y para ser merecedores de este favor, nuestro primer deber es proteger la fe cristiana y su venerable religión. Por lo cual, considerando que la preeminencia de la Sede Apostólica está asegurada por los méritos de San Pedro, el primero de los obispos, por el primer lugar de la ciudad de Roma y también por autoridad del santo sinodo, que no se presuma mostrar nada contrario a la autoridad de esa Sede. Pues la paz de las iglesias se preservará en todas las partes cuando todo el cuerpo reconoce a su gobernante. Hasta ahora esto ha sido observado sin ninguna violación; pero, Hilario, Obispo de Arlés, según hemos sabido por el informe de la venerable persona de León, el papa de Roma, se ha aventurado, 
con atrevimiento contumaz, a ciertos procedimientos ilegales; $y$ asi una confusión abominable ha invadido la iglesia al otro lado de los Alpes [...] La confianza en el Imperio y el resto de nuestro gobierno son destruidos por tales actos arrogantes. Por tanto, reprimimos primero el crimen; $y$, después, para impedir que nazca perturbación entre las iglesias, por pequeña que sea, y para que la disciplina de la religión de ninguna manera se menoscabe, decretamos por un edicto perpetuo que nada intenten los obispos galos o de cualquier otra provincia contrario a la costumbre antigua sin la autoridad del venerable papa de la Ciudad Eterna. Que sea ley para todos los que la autoridad de la Sede Apostólica ha promulgado o promulgue. Por tanto, si un obispo citado a la presencia del papa de Roma desdeña presentarse, que el gobernador de la provincia le obligue a hacerlo".

f) Epístola del papa León Magno al emperador Teodosio II para solicitar la convocatoria de concilio. El cual resultó ser el Concilio de Éfeso, año 449 -conocido como el "latrocinio de Éfeso"-, en el que el Obispo Dióscuro de Alejandría con el apoyo del emperador Teodosio II logró deponer al obispo Flavio de Constantinopla y silenciar a los legados papa les -a cambio, se empezó a sentar las bases de la doctrina Sacerdosimperator-, tras el mismo, el papa escribió al emperador para convocar otro concilio, pero esta vez en Italia, para revocar los actos del anterior): "León obispo y el santo sinodo que se ha reunido en la ciudad de Roma, al emperador Teodosio. La carta que ha sido enviada a Vuestra Clemencia hace poco tiempo a la sede del beato Apóstol Pedro por amor a la fe católica nos ha infundido tanta confianza de que la verdady la paz sean defendidas por Vosotros que hemos sido inducidos a pensar que no pueda existir ningún elemento nocivo en una causa tan simple e importante. Y esto, de manera especial, porque aquellos que fueron enviados al concilio de los obispos, que por orden tuya se ha reunido en Éfeso, están tan bien preparados que, si el obispo de Alejandría bubiese permitido dar a conocer a los obispos los escritos que habian llevado consigo, o al santo sinodo o al Obispo Flaviano, con la manifestación de la fe purísima que hemos recibido de la tradición y conservamos como totalmente inspirada, se habria encontrado motivo para provocar daño. Pero cuando, bajo el pretexto de religión, se hace valer intereses privados, la impiedad de pocas personas provoca heridas a toda la Iglesia. Hemos tenido conocimiento de lo que ha sucedido, no a través de un mensajero poco fiable, sino por el contrario, de un fidelisimo informador, a saber, a través de Hilario, nuestro diácono, que con gran dificultad logró huir para no tener que verse obligado a firmar a la fuerza: se reunieron en el sinodo muchisimos obispos cuya numerosa presencia hubiese sido útil para las deliberaciones $y$ las decisiones si aquel que reclamaba para si el primer puesto hubiese querido mostrar la moderación que es propia de un sacerdote; todos habrian expresado, como es costumbre, suparecer en libertad y después de un examen realizado con calma y sentido de la justicia, habrian establecido lo que está de acuerdo con la 
fe y puede ayudar a quienes están en el error. Pero hemos sabido que, incluso en esta decisión, no tomaron parte para todos los que se habian reunido, pues hemos sabido que algunos fueron expulsados [...]".

g) Carta del papa Gelasio al emperador Anastasio I "Gelasius papa-epistola Romanorum Pontificium: De regno et sacerdotio", año 494. Este texto marca el inicio de la doctrina del dualismo gelesiano, basada en la potestas indirecta -tomada de Ambrosio de Milán, en su respuesta al emperador Teodosio- ${ }^{9}$, haciendo famosa la metáfora de "las dos espadas", que continuará el papa Gregorio Magno (ministerium regis), aunque luego dicha fórmula se volverá en contra de la Iglesia, primero en Bizancio y luego con Carlomagno). "Hay, en verdad, augustisimo emperador, dos poderes por los cuales este mundo es particularmente gobernado: la sagrada autoridad de los papa s y el poder real. De ellos, el poder sacerdotal es tanto más importante cuanto que tiene que dar cuenta de los mismos rey es de los hombres ante el tribunal divino. Pues has de saber, clementisimo hijo, que, aunque tengas el primer lugar en dignidad sobre la raza humana, empero tienes que someterte fielmente a los que tienen a su cargo las cosas divinas, y buscar en ellos los medios de tu salvación. Tú sabes que es tu deber, en lo que pertenece a la recepción y reverente administración de los sacramentos, obedecer a la autoridad eclesiástica en vez de dominarla. Por tanto, en esas cuestiones debes depender del juicio eclesiástico en vez de tratar de doblegarlo a tu propia voluntad. Pues si en asuntos que tocan a la administración de la disciplina pública, los obispos de la iglesia, sabiendo que el imperio se te ha otorgadopor la disposición divina, obedecen tus leyes para que no parezca que hay opiniones contrarias en cuestiones puramente materiales, ¿con qué diligencia, pregunto yo, debes obedecer a los que han recibido el cargo de administrar los divinos misterios? De la misma manera que hay gran peligro para lospapa scuando no dicen lo que es necesario en lo que toca al honor divino, asi también existe no pequeño peligro para los que se obstinan en resistir (que Dios no lo permita) cuando tienen que obedecer. Y si los corazones de los fieles deben someterse generalmente a todos los sacerdotes, los cuales administran las cosas santas, de una manera recta, ¿cuánto más asentimiento deben prestar al que preside sobre esa sede, que la misma Suprema Divinidad deseó que tuviera la supremacia sobre to dos los sacerdotes, y que el juicio piadoso de toda la Iglesia ha honrado desde entonces?".

9 Fórmula: "In causa fidei episcopos solere de imperatoribus Christianis iudicare" ["En las causas que se refieren a la fe, corresponde a los obispos juzgar a los emperadores cristianos"]. 


\section{Mundo MEDIEVAL Y TENSIONES DEL DUALISMO}

De la antigua concentración de poder se pendula a su dispersión, de geometría variable medieval, fragmentándose el poder y dando lugar a focos de conflicto entre Occidente/Roma y Oriente/Constantinopla. Así se explica que pese a que ya en este periodo histórico-cultural se tiene clara la existencia de la dualidad (e.g. poder terrenal-poder espiritual, comunidad política-comunidad religiosa, orden temporal-orden eterno), no se puede decir lo mismo de la interpretación de su contenido. La epístola De regno et sacerdotio -aprovechando la debilidad del emperador occidental- y la Novela Basilea -aprovechando la fortaleza del emperador oriental-sientan las bases teóricas del debate entre la potestas imperial y la auctoritas papa 1, y como ya pasara con la declaración evangélica de Jesucristo sobre la dualidad (e.g. Mt. 22, Mc. 12, Lc. 20: véase más abajo), su contenido empieza a ser distorsionado a través de inferencias, imposturas y falacias, bien a favor del emperador (periodo cesaropapista, siglos IV-X, donde el poder religioso está sometido al civil), bien en beneficio del papa (periodo hierocratista, siglos $\mathrm{XI}-\mathrm{XV}$, donde el poder civil pasa a estar a disposición del religioso). Surgen así diversas te orías kratológicas, como las de la potestad indirecta y directa o de la autoridad mediata e inmediata -con sus metáforas correspondientes-, por las que se pretende legitimar la invasión de esferas (e.g. el poder civil convoque concilios; el Obispo de Roma exija ser reconocido como primado y príncipe de príncipes). Finalmente, todas estas tensiones conducirán al enfrentamiento directo entre el emperador y el Papa, dando lugar a las guerras de investiduras y excomuniones, así como, a la deslegitimación de sendos mandos, lo que es aprovechado por las emergentes monarquías modernas para copar el vacío de poder.

\section{Textos cesaropapistas: Proclamas y donaciones (potestad indirecta y directa).}

El cesaropapismo constituye la presunción de la preeminencia del poder civil sobre el religioso. Se inaugura con el emperador Constantino (se consolida con Teodosio, a finales del s. IV, y llega hasta Fernando III, a mediados del siglo XI), quien autoproclamó su episcopalidad y antes de convertirse al cristianismo -conociendo el poder local de la administración eclesiástica y la conveniencia de su sometimiento- convoca el Concilio de Nicea en el año 325. De este modo se asegura la continuidad del Imperio pese a su escisión entre Occidente y Oriente, que es donde traslada su corte -al ser la parte más rica y suntuosa del antiguo Imperio-. Dicha cuestión no es baladí, pues se aprovechan todas las circunstancias mencionadas para falsificar la historia y del derecho con una serie de documentos en forma de donaciones. 
Lo curioso es que la idea inicial no parte del poder religioso, sino del civil, cuando Pipino el Breve (padre de Carlomagno) pretende erigirse como rey de los francos y heredero del Imperio Romano de Occidente, por lo que además de prestar ayuda militar al papa frente a los lombardos, hace circular una donación sobre los Estados Pontificios, a cambio de ser reconocido por la autoridad del papa -evitando así represalias y el morbus gotichus-. Sin embargo, esta sintonía cesa con Carlomagno, quien rechaza la coronación de mano eclesiástica, reafirmando así su posición como poder elegido por Dios -aunque el cesaropapismo decaerá, tal planteamiento servirá para el emergente absolutismo, siglos después-.

a) Novela Basilea o doctrina auctoritas-potestas ("Corpus Iuris Civilis", Novella VI, año 530 aprox., por el emperador Justiniano; desarrollo de las relaciones Iglesia-Estado en el libro XVI del Código Teodosiano): "[...] los dones más grandes que Dios, en su clemencia celestial, otorga a los hombres son el sacerdocio y la autoridad imperial. El primero cuida de las cosas divinas. La segunda preside sobre las cosas humanas y cuida de ellas. Ambos proceden de una y misma fuente y juntos son los ornamentos de la vida humana. Por consiguiente, nada hay más querido de los emperador es que el bienestar moral del sacerdocio, puesto que los sacerdotes tienen el deber de rogar constantemente a Dios por los emperador es mismos. Pues si el sacerdocio está libre de todo vicio en todas las cosas y lleno de Dios, y si la autoridad imperial impone el orden con justicia y eficacia en la comunidad a ella confiada, habrá una armonia ideal para proveer de lo que sea útil a la bumanidad. Tenemos, por tanto, el más grande interés por las verdaderas doctrinas de Dios y por el bienestar moral del sacerdocio, por medio del cual, si es conservado, creemos que Dios nos ha de conceder los dones más grandes, y conservaremos intactas las cosas que poseemos, y además recibiremos los beneficios que ahora no tenemos. Pero todo es hecho correctamente y con eficacia si el principio es digno y agradable a Dios. Estamos convencidos de que asi sucederá si se observan cuidadosamente los sagrados cánones, dados por los apóstoles, justamente alabados, y testigos venerados y siervos de la palabra de Dios, y que los santos padres conservaros e interpretaron [...]".

b) Donación de Pipino el Breve ("Donatio Pippinii per liber pontificalis", en Monumenta Germanae Historica: Capitularia Regum Francorum, año 756, en las proximidades de Pavía): “[...] un mensajero imperial se apresuró a ir a la presencia del mencionado rey de los francos. Lo encontró más acá de la frontera lombarda, no lejos de la ciudad de Pavia, y le rogó urgentemente, con la promesa de muchos presentes imperiales, que entregara a las autoridades imperiales la ciudad de Rávena y las otras ciudades y los lugares fortificados del Exarcado. Pero no pudo persuadir al fuerte corazón de ese cristianisimo y benévolo rey, que era fiel a Dios y amaba a San 
Pedro, es decir, Pipino, rey de los francos, a entregar esas ciudades y lugares a la autoridad imperial. Ese mismo amigo de Dios, muy bondadoso rey, se negó rotundamente a enajenar eses ciudades del poder de San Pedro y de la jurisdicción de la Iglesia Romana o del Pontifice de la Sede Apostólica. Afirmó bajo juramento que no habia hecho la guerra tantas veces para obtener el favor de nadie, sino por el amor de San Pedro y por la remisión de sus pecados, y declaró que el acrecentamiento de su tesoro no le persuadiría a quitar lo que una vez habia ofrecido a San Pedro [...] habiendo adquirido todas esas ciudades, redactó un documento de donación para la posesión perpetua de ellos por San Pedro y la Iglesia Romana y por todos los Pontifices de la Sede Apostólica. Este documento todavia existe en los archivos de nuestra Santa Iglesia [...]".

c) Donación de Constantino (año 755 aprox.; descubierta la falsificación hacia el 1430, con corrección posterior mediante Donación itálica o Acta de los Electores alemanes confirmando la entrega de Italia al Papa do por Rodolfo de Habsburgo, año 1279): “[...] Concedemos a nuestro Santo Padre Silvestre, Sumo Pontifice y papa universal de Roma, y a todos los pontifices sucesores suyos que hasta el fin delmundo reinarán en la Sede de San Pedro, nuestro palacio imperial de Letrán (el primero de todos lospalacios del mundo). Después la diadema, esto es nuestra corona, y al mismo tiempo el gorro frígio, es decir, la tiara, el manto que suelen usar los emperador es y además el manto purpúreo y la túnica escarlata y todo el vestido imperial, y además también la dignidad de caballeros imperiales, otorgándoles también los cetros imperiales y todas las insignias y estandartes y diversos ornamentosy todas la prerrogativas de la excelencia imperial y la gloria de nuestro poder [...] Por ello, hemos considerado oportuno transferir nuestro Imperio y el Poder del reino a Oriente y fundar en la provincia de Bizancio, lugar óptimo, una ciudad con nuestro nombre y establecer allí nuestro gobierno, porque no es justo que el emperador terreno reine donde el emperador celeste ha establecido el principado del sacerdocio y la cabeza de la religión cristiana [...]" [Donación de Constantino]. "Nosotros, los principes del imperio a todos los que vean el presente documento [...] y para que nosotros, que estamos obligados a favorecer pro igual a la Iglesia y al Imperio, aparezcamos, en deseos como en hechos, como hijos devotos de la paz, aprobamos y ratificamos todo lo que ha sido reconocido, confirmado, ratificado y renovado, otorgado de nuevo, declarado o concedido, jurado, dado y acordado por nuestro señor Rodolfo, por la gracia de Dios rey de los Romanos, siempre Augusto, a nuestro Santísimo Padrey Señor, el papa Nicolás III, a sus sucesores y a la Iglesia Romana, por medio deprivilegios uotros documentos escritos, en los que se contienen reconocimientos, ratificaciones, aprobaciones, renovaciones, confirmaciones, donaciones, concesiones hechas por este presente rey y por otros emperador es romanos y rey es, sus antecesores, particularmente si tratan de la fidelidad, obediencia, honory reverencia debidos 
por los emperador es romanos y rey es a los pontifices romanos y a su iglesia, $y$ de las posesiones, honores y derechos de esta iglesia. En particular en lo que se refiere a todo el territorio que se extiende desde Radicofano a Ceperano, la Marca de Ancona, el Ducado de Espoleto, lasposesiones de la Condesa Matilde, las ciudades de Rabean, Emilia, Bobbio, Cesana, Forlimpopoli, Forli, Faenza, Imola, Boloña, Ferrara, Comachio, Adria, Cabello, Urbino, Montefeltro, el territorio de Baño, el pais de Bertinoro, el exarcado de Rávena, Pentápolis, Massatrabaria con sus territorios y todas las otras tierras quepertenecen a dicha iglesia, con todas las marcas, territorios e islas que pertenecen en algún modo, tanto por tierra como por mar, a las citadas provincias, poblaciones, territorios $y$ localidades. Y también en relación con la ciudad de Roma con todas suspertenencias y el reino de Sicilia en ambas orillas del estrecho de Mesina, y Córcega y Cerdeña, y todas las otras tierras y derechos pertenecientes a esa iglesia [...]" [Donación itálica].

d) [Juramento de la] Constitución romana ("Constitutio Romana”, año 824, por el emperador Lotario I; complementariamente, véase el juramento de vasallaje de Juan sin Tierra en el siguiente punto): “[...] prometo por Dios Todopoderoso, porlos cuatro santos evangelios, por esta cruz de Nuestro Señor Jesucristo y por el cuerpo del muy bendito Pedro, Principe de los Apóstoles, que desde hoy hasta el fin de mis dias seréfiel a mis señores los emperador es Luis y Lotario, en cuanto misfuerzas y conocimiento me lo permitan, salvo la fe que he prometido al señor apostólico. Y que no consentiré, en cuanto mis fuerzas y conocimiento me lo permitan, que la elección del romano pontifice a esta sede romana sea hech a de otra manera que no sea canónica y legal. Y que el que sea elegido con mi consentimiento, no será consagrado pontifice hasta que no haya prestado este juramento en la presencia del enviado del emperador y del pueblo junto con el juramento que el señor papa Eugenio escribió de su propia voluntad para la conservación de todas estas cosas [...]".

2. Textos hierocratistas: cánones, decretos y bulas (autoridad mediata e inmediata).

Si en el periodo anterior, el emperador ha pretendido asumir la simbología papa 1 (la episcopalidad constantiniana y catolicidad teodosiana) para revestirse de su autoridad y, de este modo, lograr someter el poder religioso al civil, bajo la amenaza de la violencia física. No es de extrañar entonces que, por los excesos, se produzca una dinámica pendular, como es el hierocratismo, que significa literalmente el poder jerárquico de las elites eclesiásticas. Se inaugura así un periodo de sometimiento del poder civil al religioso, pero esta vez bajo amenaza de la violencia discursiva: a) argumentos mejor elaborados (e.g. autoridad mediata e inmediata); b) mayores aportes de evidencias (e.g. donaciones, decretos); c) amenazas de excomuniones (vid. siguiente punto); 
etc. Gracias a las prácticas conciliaristas y las exigencias de privilegios, se están sentando así las bases de la cultura democrática y iushumanista, en el momento en que la misma se abra a toda la población y ésta pueda participar también del poder y de los derechos.

a) Cánones del Concilio de Reims ("Ecclesiasticum ministerium", año 1049): "I. Que nadie sea ascendido al gobierno de una iglesia sin ser elegido primero por el clero y el pueblo. II Que nadie compre o venda las órdenes sagrada u oficios eclesiásticos o iglesias; $y$ si algún clérigo ha comprado algo de esta naturaleza, que los entregue a su obispo y haga la penitencia debida. III Que ningún seglar reciba oficio eclesiástico o iglesia, y que ningún obispo consienta en esto. IV Que nadie sino el obispo o su representante se atreva a pedir dinero a las puertas de las iglesias. V Que nadie demande pago por funerales o por administrar el bautismo o la eucaristía o por visitar a los enfermos. VI Que los clérigos no lleven armas o se dediquen a ocupaciones mundanas [...]".

b) Decretos del papa Nicolás II ("In nomine Domini", "Pontificis electione”, contra la investidura seglar, año 1059; previamente, "Epístolas del Cardenal Humberto", año 1054-58): "Nicolás, obispo, siervo de los siervos de Dios, a todos los obispos católicos y a todo el clero y pueblo, saludos afectuosos y la bendición apostólica. Puesto que tenemos que ser diligentemente solícitos para todos los hombres con la vigilancia propia de nuestro cargo universal preocupándonos de nuestra salvación, hemos tomado el cuidado de enviaros los decretos promulgados en el sinodo recientemente celebrado en Roma, en presencia de ciento trece obispos y, aunque somos indignos, bajo nuestra presidencia; pues deseamos que los hagáis cumplir para vuestra salvación, y mandamos esto con autoridad apostólica: I. Inicialmente se acordó, en la presencia de Dios, que la elección del Romano Pontifice fuera hecha por los cardenales obispos de tal manera que, el que sea entronizado sin su consentimiento previo y elección canónica y sin el consentimiento posterior de otros órdenes del clero y del pueblo, no será tenido por papa y apóstol, sino por un apóstata. II. Que cuando el obispo de Roma o el de cualquier otra ciudad muera, nadie se atreva a saquear susposesiones, sino que estas deben preservarse intactas para sus sucesores. III. Que nadie oiga la misa de un sacerdote del que se sabe, con certeza, que mantiene una concubina o tiene una mujer viviendo con $e^{l} l^{10}$. Por esto el mismo santo sinodo decretó lo siguiente, bajo la pena de excomunión. El sacerdote, diácono o subdiácono que, después de la constitución sobre

${ }^{10}$ Cuestión de la castidad, que también asume el poder civil, como se ve en el ejemplo de las Partidas (Alfonso X el Sabio, 1256-65): Partida I, tít. $5^{\circ}$ ("De los prelados de la Santa Iglesia que han de mostrar la fe y dar los sacramentos"), ley $38^{a}$ : "Castos y vergonzosos deben ser los prelados en dicho y en hecho, pues aquellos que con sus manos han de consagrar el cuerpo de Jesucristo y lo tienen que recibir en si mismos, y han de dar los otros sacramentos de la iglesia, mucho conviene que tengan en si castidad y limpieza. Otrosí, 
la castidad de los clérigos, dada por nuestro santísimo predecesor el papa León, de feliz memoria, tome concubina o tomada, no la abandone, de parte de Dios Omnipetente y por la autoridad de los bienaventurados apóstoles Pedro y Pablo, ordenamos, y no oponemos en absoluto, que no cante la misa ni el evangelio [...] VI. Que ningún clérigo o sacerdote recibe una iglesia de manos de los seglares bajo ningún concepto, ya sea libremente o por un precio [...] X. Que ningún seglar juzgue o expulse de las iglesias a ningún clérigo de cualquier orden [...]" [In nomine Domini]. "[...] Apoyados en la autoridad de nuestros predecesores $y$ de los otros santos padres, decretamos y ordenamos que: cuando el pontifice de esta iglesia universal romana muera, los cardenales primero hablarán diligentemente entre ellos sobre la elección. Después citarán a los otros cardenales $y$, entonces, el resto del clero y el pueblo se aproximarápara dar su asentimiento a la nueva elección teniendo el mayor cuidado de que no intervenga en modo alguno el demonio de la penalidad [...]" [Pontificis electione].

c) Decreto del papa Gregorio VII ("Dictatus Papa e", año 1075): "[...] Que la Iglesia Romana fue fundada únicamente por Dios. Que sólo el Romano Pontifice puede, en justicia, ser llamado universal. Que sólo él puede deponer o reestablecer a los obispos. Que su legado, aunque sea de menor rango, tiene la preeminencia, en el concilio, a todos los obispos, y puede decretar sentencia de deposición contra ellos. Que el papa puede deponer a los ausentes. Que, entre otras cosas, no debemos morar en la misma casa con los que han sido excomulgados por él. Que sólo a élpertenece legalmente promulgar leyes de acuerdo a las necesidades de los tiempos, convocar nuevas congregaciones, fundar nuevas abadías canónicas, y dividir un obispado rico y unificar los pobres. Que sólo él puede usar la insignia imperial. Que el papa es el único cuyos pies deben ser besados por todos los principes. Que sólo su nombre debe ser mencionado en las iglesias. Que su titulo es único en el mundo. Que sólo a él es lícito deponer emperador es. Que sólo a él es lícito cambiar obispos, cuando sea necesario, de una sede a otra. Que sólo él tiene autoridad para ordenar clérigos de cualquier iglesia si asi lo desea. Que el que ha sido ordenado por él puede gobernar otra iglesia pero no puede estar bajo las órdenes de otros; y que ese tal no puede recibir un grado más alto de ningún obispo. Que ningún sinodo puede ser llamado general sin su consentimiento. Que ningún capitulo ni libro sean tenidos por canónicos sin su autoridad [...]".

d) Carta Magna ("Magna Charta", autonomía de la iglesia anglicana, año 1215; consagra el juramento de vasallaje de Juan sin Tierra al papa o "Vassalage to the Holy See", año 1213; previamente, Constituciones de Clarendon o Regalibus

deben tener vergüenza, pues si la tuvieran, siempre se guardarán de hacer pecado de decir lo que mal está"; véanse más abajo: IV,3: "Textos polemológicos". 
Britannico, año 1164): "Juan, por la gracia de Dios, Rey de Inglaterra, Señor de Irlanda, Duque de Normandia y Aquitania, Conde de Anjou, salud a todos los fieles cristianos que vean esta presente cédula. Es nuestro deseo que todos vosotros sepáis por esta nuestra cédula, la cual lleva nuestro sello, que, puesto que hemos ofendido a Dios y a Nuestra Santa Madre la Iglesia en muchas cosasy por lo tanto es público que necesitamos grandemente la misericordia divina, y puesto que no podemos ofrecer a Dios y a la Iglesia nada que sea digno y propio para rendir debidamente satisfacción a Dios y a la Iglesia a no ser que nos humillemos nosotros mismos junto con nuestros reinos [...] Yo, Juan, por la gracia de Dios Rey de Inglaterray Señor de Irlanda en adelante seréfiel a Dios y al bienaventurado Pedro y a la Iglesia Romana, y a mi señor papa Inocencio y a sus sucesores que suban a la Sede católica; no seré causa por obra, palabra, consentimiento o consejo de que pierdan su vida o miembro, o que sean puestos en cautividad. Impediré, si lo sé, que sufran daño, y haré remover tal perjuicio si puedo; o les informaré de ello tan pronto como sea posible, o lo comunicaré a la persona de la cual yo crea con certeza que les informará [...]" [juramento de vasallaje de Juan Sin Tierra]. "[...] La Iglesia de Inglaterra será libre, y disfrutará plenamente de derechos y libertades inviolables [...]" [capítulos $1^{\circ}$ y $10^{\circ}$ de la Magna Carta].

e) Bulas del papa Bonifacio VIII ("Clericis laicos", año 1296; "Etsi de statu", año 1297; "Asculta fili", año 1301; "Unam sanctam”, año 1302, castigo de excomunión, libertad eclesiástica, etc.): "Para perpetua memoria. El tiempo nos ha mostrado que los laicos han sido siempre hostiles en exceso con el clero. Y esto lo demuestra claramente la experiencia de los tiempospresentes, pues no contentos con sus limitaciones, los laicos desean cosas probibidas y dan rienda suelta a la búsqueda de la ganancia ilícita. Pasan prudentemente por alto que se les niega todo dominio sobre el clero asi como sobretodos las personas eclesiásticas y susposesiones, pero imponen pesadas cargas a los prelados de las iglesias, a las iglesias mismas y al clero, tanto regular como secular, haciéndoles pagar tributos [...]" [Clericis laicos] "[...] Ejercitando el deber de nuestro cargo pastoral, dimos un decreto por autoridad apostólica a favor de las iglesias y de la libertad eclesiástica, proclamando el principio de que prelados y personas eclesiásticas de cualquier lugar, rango o dignidad no debian pagar impuestos a emperador es, rey es, principes o a otros gobernantes sin la autoridad de la Sede Apostólica [...]” [Etsi de statu] “A nuestro amadísimo hijo en Cristo, Felipe, ilustre Rey de Francia. Escucha hijo, los preceptos de un padre y pon atención a la enseñanza de un maestro que ocupa en la tierra el lugar de Aquel que es el unico Señor y Maestro; pon en tu corazón el aviso de la Santa Madre Iglesia, y trata de obrar de acuerdo con él con buenos resultados para que, con un corazón dolido, vuelvas reverentemente a Dios del cual, según es sabido, te apartaste por negligencia o por consejos perversos, y confórmate a su 
voluntad y a la nuestra [...]" [Asculta fili] "Según nuestra fe estamos obligados a creer y a sostener que hay una sólo Iglesia, Santa, Católica y Apostólica, y esto creemos firmemente y confesamos simplemente; y también que no hay salvación ni perdón fuera de ella, como el esposo dice en el Cantar: "una es mi paloma, mi paloma perfecta es una sola; es la única de su madre, la escogida de la que le dio el ser", la cual representa un solo cuerpo mistico, cuya cabeza es Cristo; y Dios es la cabeza de Cristo. Y en ella hay "un solo Señor, una sola fe, un solo bautismo" [...] Por tanto, hay en esta sola y unica Iglesia un solo cuerpo y una sola cabeza, no dos cabezas como si fuera un monstruo; a saber, Cristo, y su vicario y sucesor Pedro [...] Por consiguiente, los griegos y los otros dicen que ellos no fueron confiados a Pedro ni a sus sucesores, confiesan de necesidad que ellos no son de las ovejas de Cristo, pues el Señor dice a Juan: "babrá un solo rebaño y solo pastor" [...] Y el que niegue que la espada temporal está comprendida en el poder de Pedro, ha entendido mal la palabra del Señor, cuando dice: "toma la espada a su lugar". De donde ambas se contienen en el poder de la iglesia; esto es, las espadas espiritual y temporal; la una, para ser utilizada a favor de la Iglesia, y la otra, por la Iglesia; la primera, por el sacerdote, la última, por la mano de rey es y caballeros pero a voluntad y con consentimiento tácito del sacerdote. Pues es necesario que una espada esté subordinada a la otra, y que la autoridad temporal esté sujeta a la espiritual. Pues cuando el apóstol dice: "todo poder procede de Dios y los poderes que existen son ordenados por Dios", no estarían ordenados si una espada no estuviera bajo la otra espada, y lo inferior, por así decir, no fuera preservado para ser conducido a hechos ilustres. Porque, según el bienaventurado Dionisio, es la ley de la divinidad que lo más bajo tiene que ser guiado por lo más alto [...]" [Unam sanctam].

3. Textos polemológicos: correspondencias y concordatos (guerras de investiduras y excomuniones).

a) Se trata de un periodo de crisis, de convulsiones correctoras para alumbrar el Nuevo Régimen por llegar. Es una época de luchas cruentas y quiebra de creencias -la Reforma Protestante, en realidad, sólo es la consecuencia lógica de este momento-, recordada por los historiadores como las Gue r ras de investiduras y excomuniones - para la gente que vivió aquello, sin duda, suponía el fin del mundo, de ahí la emergencia de los movimientos milenaristas, trasladados a América, que al ser descubierta y colonizada es considerada como el Edén o Nueva Jerusalén-. Pero como todas las crisis, finalmente, dan paso a nuevos estadios, con sus experiencias y concepciones -ergo, nuevos paradigmas-: se abandona el mundo de lo blanco o negro (e.g. terrenal-celestial, temporal-eterno, papal-imperial), para empezar a descubrir las gamas de grises, con las monarquías, los descubrimientos, los inventos, los derechos, etc. Desafortunádamente, para que emerjan los grises y se tome 
conciencia de los mismos -aprendiendo a distinguir mejor los contornos de cada orden o esfera social-, resulta necesario para el hombre de entonces pasar por el trauma de las Guerras de investiduras y excomuniones, que tienen su origen en correcciones de intromisiones (vid. textos anteriores) ${ }^{11}$, así como, la escalada de tensión, constatable en textos político-jurídicos como: i) Epístolas del papa Gregorio VII a los emperador es de su tiem po para reclamar su primacía bajo amenaza de excomunión y por tanto perdida de legitimidad para ostentan su poder (e.g. al rey franco Felipe I, año 1073; a los rey es hispanos Alfonso VI y Sancho II, año 1074; al rey húngaro Salomón, año 1074; al rey danés Swen, año 1075; al rey ruso Demetrio y esposa, año 1075; al emperador Romano-Germano Enrique IV, años 1076-80); i) Correspondencia entre el papa Adriano IV y el emperador Federico I, con mutuas amenazas (e.g. amenaza papa l, año 1157; manifiesto imperial, año 1157); i) Decretal del papa Inociencio IV para deponer al emperador Federico II, año 1245; i) Breve Papa 1 "Meruit" (sobre la integridad eclesiástica, del papa Clemente V al rey francés Felipe, año 1306); y los todos los demás documentos del s. XIV, mejor conocidos y por ello se obvia su enunciación en este trabajo).

b) Concordato de Worms (entre el papa Calixto II y el emperador Enrique V, año 1122): "Privilegio del emperador : en el nombre de la Santa e Indivisible Trinidad. Yo, Enrique, por la gracia de Dios, emperador augusto de romanos, por el amor de Dios y el de la Santa Iglesia Romana y por el del señor papa Calixto y por la salvación de mi alma, entrego a Dios, a los santos apóstoles de Dios, Pedro y Pablo, y a la Santa Iglesia Romana toda investidura por medio del anillo y el báculo, y acepto el que se celebren elecciones canónicas y consagración libre en todas las iglesias en todo mi reino y a través del imperio. Devuelvo a dicha iglesia romana todas las posesiones y temporalidades tomadas [...] Privilegio del Papa: yo, Calixto, obispo, siervo de los siervos de Dios, te concedo a ti, amado hijo Enrique, augusto emperador de romanos por la gracia de Dios, el que la elección de los obispos y abades en el reino alemán que pertenezcan al reino, sea hecha en tu presencia y sin simonía y sin violencia, para que en el caso de haya alguna discordia entre las partes interesadas, puedas con el consejo y juicio del metropolitano y de los comprovinciales dar tu asentimiento [...] te otorgo paz verdadera a ti y a todos los que son o han sido de tu partido durante esta discordia [...]".

c) Paz de Venecia (entre el emperador Federico I y el papa Alejandro III, año 1177): “[...] el señor emperador Federico, así como

${ }^{11}$ Sirva como ejemplo el caso de las investiduras: si el Papa Nicolás II reivindicó en sus decretos que la investidura papa 1 fuera eclesiástica, lo mismo se reclama para la elección imperial, que se desea resulte secular, véase el Decreto Licet iuris del emperador Luis dado por la Dieta de Frankfurt, en el año 1338. 
ha recibido al señor papa Alejandro como papa católico y universal, de la misma manera le mostrará la debida reverencia como sus antecesores católicos la mostraran a los predecesores católicos de Alejandro. También observará la misma reverencia a los sucesores del papa que sean católicamente entronizados. $Y$ también el señor emperador restaurará la paz al señor papa Alejandro, a sus sucesores y a toda la Iglesia Romana. Devolverá de buena fe, salvo los derechos del imperio, toda posesión o pertenencia, ya sea de prefectura o de otra cosa, que poseyera la Iglesia Romana y que él arrebató personalmente o por medio de otros. Igualmente, la Iglesia Romana restaurará de buena fe toda posesión o pertenencia que tomó de él por si misma o por medio de otros, salvo todos los derechos de la Iglesia Romana [...]".

d) Concordato de Viena entre el papa Nicolás V y el emperador Federico III (modificaciones de bulas, Viena, año 1448): "En el nombre del Señor amén. En el año mil cuatrocientos cuarenta y ocho de la Natividad del Señor, en el decimoséptimo día del mes de febrero, el concordato abajo descrito, fue concluido, confirmado y aceptad por el muy santo padre en Cristo y nuestro señor Nicolás, papa por la providencia divina, quinto de su nombre, y la Sede Apostólica, de un lado, y la nación germánical alemana del otro; fue concluido en nombre de nuestro santísimo señor y en el de la Sede Apostólica por el muy reverendo padre en Cristo, el señor Juan [Carvajal] cardenal legado de la santisima iglesia romana, con autoridad y poder completos, y en nombre la nación alemana por el gloriosisimo principe y nuestro señor Federico, Rey de Romano, siempre augusto, etc., con el consentimiento y adhesión de varios electores del Sacro Imperio Romano [Germano], y de otros principes de esta nación, tanto eclesiásticos como seculares. En relación a la provisión de iglesias y de todos los beneficios, nuestro santísimo señor el papa Nicolás $V$ invoca las reservas de la ley escrita y de las bulas modificadas en los siguientes términos [...]".

e) Acta/Ley de Supremacía de Enrique VIII (1534): "Se decreta que el Rey, nuestro Soberano, sus herederos y sucesores rey es de este reino, aceptados y tenidos como Cabeza Suprema en la tierra de la Iglesia de Inglaterra, llamada "Anglicana Ecclesia", y que posean y disfruten la Corona Imperial aneja y unida a este reino, de su titulo y asignación, asi como de todos los honores, dignidades, jurisdicciones, privilegios, facultades, inmunidades, útiles y bienes propios y los pertenecientes a la dignidad de Cabeza Suprema de esta Iglesia. Y que dicho Soberano y Señor nuestro, sus herederos y sucesores rey es de este reino, tengan poder y autoridad plenos para castigar, reprimir, reformar, corregir, regular, frenar y enmendar estos errores, herejias, abusos, ofensas, desprecios y excesos de cualquier género de sean, que de cualquier modo pudiesen o debiesen ser legalmente reformados, reprimidos, reparados, corregidos, frenados o enmendados por la autoridad o jurisdicción espiritual. Todo ello 
para gloria de Dios Omnipotente y para el incremento de las virtudes cristianas primeramente y después para la conservación de la paz, unión y tranquilidad del reino, no obsta/sin obstáculo por cualquier uso, costumbre, prescripción, ley o autoridad extranjera y cosa contraria".

\section{MUNDO MODERNO Y DificUlTADES DEL PLURALISMO Y LA ACOMODACIÓN DE ÓRDENES}

1. Textos otorgados y pactados: de reales cédulas y cartas otorgadas a declaraciones de derechos (concesiones de alteridad y exigencias de autonomía).

La providencia (divina) deja paso al progreso (humano), el hombre, imbuido de la confianza en su razón, comienza a discernir mejor su realidad, con sus complejidades, logrando una gestión más efectiva de las relaciones sociales, en sus diversas esferas. Ahora bien, ¿habría sido posible el tránsito a la Modernidad sin tanta violencia, desvíos y rectificaciones? Sirva de ejemplo el caso de España, cuyo comienzo como monarquía moderna resulta prometedora y prototípica: $i$ ) reunificación de los reinos medievales y vertebración administrativa; ii) descubrimiento de nuevas tierras y pueblos; iii) establemiento de relaciones diplomáticas con las monarquías vecinas emergentes; etc.; sin embargo, el proyecto moderno de los Trastámaras (los Rey es Católicos) se trunca con las aspiraciones anacrónicas imperiales de su nieto, Carlos -también nieto de Maximiliano, el emperador del Sacro Imperio Romano Germánico: de ahí la explicación-. De este modo, el tránsito a la Modernidad queda comprometido, generando un sinfín de oscilaciones que, a la postre, hacen que España termine aterrizando en la Posmodernidad. Luego, si se compara la trayectoria americana y europea, sin dificultad se pueden observar las diferencias entre la Modernidad estadounidense (de una secularización temprana e inacabada, posibilitadora de una separación acomodaticia realista entre Religión-Política-Derecho), frente a la Posmodernidad española (de una secularización tardía culminada y muy discursiva, con independencia entre las esferas sociales -incluso, con suspensión de algunas de ellas, e ignoramientos entre sí-). Sin embargo, la evidenciación de tales postulados supera el marco temporal comprometido para este trabajo, por lo que, a continuación, únicamente, se ofrecen los textos de contrastación básica.

La siguiente selección de fuentes pretende evidencias que, el tránsito a la Modernidad, supone también el cambio de régimen (del Antiguo al Nuevo Régimen), y con ello, se pasa de una cultura del Derecho a la de los derechos. A este respecto, se evidencian, las diferencias entre el desarrollo 
de la cultura político-jurídica anglosajona, de reivindicación autónoma ${ }^{12}, \mathrm{y}$ la europea-continental, de concesión heterónoma ${ }^{13}$.

a) Reales Cédulas a los caciques indios (año 1542 y 1555 , en Madrid, por Carlos I de las Españas y V de las Alemanias. Se rompe con el incipiente liberalismo impulsado por los Reyes Católicos en sus Instrucciones del 1501 y las "Leyes de Burgos" del 1512, para tornar hacia un paternalismo imperial): "[...] Y porque nuestro principal intento y voluntad siempre ha sido y es la conservación y aumento de los indios y que sean instruidos y enseñados en las cosas de nuestra santa fe católica y bien tratados

${ }^{12}$ Se trata de Royal Charters [cartas reales] donde el rey -y monarca después-, no concede derechos a sus súbditos -que muchos son sus pares, y él sólo el primero entre ellos: primus inter pares-, sino que se ve compelido a reconocerlos y protegerlos como parte del compromiso social y de gobierno, que poco a poco se va reconociendo a la mayor parte de la población; véanse: The Charter of Liberties of Henry I (1100), The Oxford Charter of Stephen (1136), The Charter of Henry II (1154), Magna Carta (1214-15), Letters Patent to Sir Humphrey Gilbert (1573), First Charter of Virginia (1606). Otros textos político-jurídicos en la misma línea pactista: Laws and Orders concluded by the Virginia General Assambly (1624), Petition of Rights (England, 1628), Charter of Massachusetts Bay (1629), The Charter of Maryland (1632), Pilgrim Code of Law (1636), An Act for the Liberties of the People (Maryland, 1638), Maryland Act Concerning Religion (1639), Fundamental Orders of Connecticut (1639), Massachussetts Body of Liberties (1641), Articles of Confederation for the United Colonies of New England (1643), The Laws and Liberties of Massachussetts (1647), Acts and Orders (Rhode Island, 1647), Connecticut Code of Laws (1650), An Act concerning our liberties (Massachussetts, 1661), The Charter of Connecticut (1662), The Charter of Rhode Island and Providence Plantations (1663), General Laws and Liberties of Massachussetts (1672), Habeas Corpus Act (England, 1679), Laws and Liberties of New Hampshire (1682), Penn's Charter of Liberties (1682), New York Charter of Liberties (1683), Bill of Rights (England, 1689), Charter of Privileges of Pennsylvania (1701), The Charter of Delawer (1701), The Charter of Georgia (1732), Articles of Association (1774), Appeal to the Inhabitants of Quebec (1774), Declaration and Resolves of First Continental Congress (1774), Rights of the Colonist (1774), Second Declaration of the Continental Congress (1775), Virginia Declaration of Rights (1776), Pennsylvania Declaration of Rights (1776), Maryland Declaration of Rights (1776), Pennsylvania Declaration of Rights (1776), Delaware Declaration of Rights (1776), Articles of Confederation (177781), North Caroline Declaration of Rights (1780), Massachussetts Declaration of Rights (1780), New Hampshire Declaration of Rights (1784), Northwest Ordinance (1787), Constitution of the United States of America (1787).

${ }^{13}$ Resulta curioso que, pese a ser con la Escuela de Salamanca cuando se alcanza el mayor grado de sofisticación en la teoría del tiranicidio -adoptada luego por los revolucionarios estadounidenses para legitimar su independencia-, en cambio, se quedan sus propuestas en el mero mundo de las ideas, permitiéndose el avance y consolidación del Absolutismo: el monarca pasa a estar por encima de todos y todo -incluida la ley del positivismo formalista-. Así se entiende el ir y venir de las concesiones graciosas -como gracia o favor del monarca- de derechos tal como se contempla en el punto siguiente. 
comopersonas libres y vasallos nuestros que lo son, encargados y mandamos a los del dicho nuestro Consejo tengan siempre gran atención y especial cuidado como todo de la conservación y buen gobierno y tratamiento de los dichos indios y de saber cómo se cumple y ejecuta lo que por Nos está ordenado y se ordenare para la buena gobernación de nuestras Indias [...]" (1542). "Ordenamos y mandamos que las leyes y buenas costumbres que antiguamente tenian los indios para su buen gobierno y administración, y sus usos y costumbres observados y guardados después de ser cristianos, y que no se contradigan con nuestra sagrada religión ni con las leyes de este libro, y las nuevas que han hecho y ordenado, se guarden y ejecuten. Y siendo necesario, por la presente las aprobamos y confirmamos, en tanto Nos podamos añadir lo que fuéremos servido y nos pareciere que conviene el servicio de Dios Nuestro Señor y al nuestro, y a la conversación y administración cristiana de los naturales de aquellas provincias, no perjudicando a lo que tienen hechos, ni a las buenas y justas costumbres y estatutos suyos [...]" (1555).

b) Real Cédula sobre los delitos contra los indios (año 1593, en Madrid, por Felipe II de las Españas. Esta real cédula hay que ponerla en contexto con las Ordenanzas de descubrimiento, nueva población y pacificación de las Indias de 1573, de los Virrey es y las Reales Audiencias): "Ordenamos y mandamos que sean castigados con mayor rigor los españoles que injuriasen u ofendiesen o maltrataren a indios, que si los mismos delitos se cometiesen contra españoles, y los declaramos por delitos públicos [...]".

c) Edicto de Nantes (año 1598, en Nantes, por Enrique IV de Francia, (antiguo hugonote y católico converso, revocado mediante el Edicto de Gracia de Alés, entre 1626-29, por el cardenal Richelieu, secretario del rey Luis XIII, volviéndose a perseguir a los hugonotes con el rey Luis XIV): "Enrique, por la gracia de Dios Rey de Francia y de Navarra, a todos los presentes y futuros. Saludos. Entre la gracia infinita que Dios quiso concedernos, es la más notoria y notablepordarnos el poder y la fuerza para no ceder al terrible desorden, confusión y trastornos que prevalecieran en nuestra llegada al reino. El campo estaba tan destrozado por innumerables facciones y sectas que el más legitimo de todos los partidos fue menor en número. Dios nos ha dado fuerzas para estar en contra de esta tormenta, hemos superado definitivamente las olas $y$ de hecho nuestro puerto de la seguridad, la paz para nuestro estado. Para que su sea la gloria por todo en todos, y la nuestra un reconocimiento libre de su gracia en hacer uso de nuestro instrumento en el buen trabajo [...] Imploramos y esperamos de la divina bondad de la misma protección y el favor que le ha concedido a este reino desde el principio [...] Tenemos, por este edicto perpetuo e irrevocable, establecida y proclamada y lo hacen, establecer y proclamar: [...] III. Nos ordenamos que la religión católica, apostólica y romana será restaurada y restablecida en todos los lugares y localidades de nuestro reino y de los paises sujetos a nuestro dominio, cuando el ejercicio de la misma haya sido interrumpido, 
con el fin de su pacifico y libre ejercicio, sin ningún problema o impedimento; prohibiendo expresamente a todas las personas, de cualquier lugar, calidado condición, el perturbar o molestar a los eclesiásticos en la celebración del culto, en el disfrute o el cobro de los diezmos, o los ingresos de sus beneficios, y todos los demás derechos y tasas que les pertenecen; y que todos aquellos que durante los disturbios hayan tomado posesión de las iglesias, casas, bienes o ingresos, pertenecientes al clero, han de reintegrar su posesión y disfrute pacifico de tales derechos, libertades y garantías como lo habian hecho antes de que fueron privados de ellos [...] VI. Y para no dejar ninguna oportunidad para los problemaso diferencias entre nuestros temas, nospermitimos, bajo la presente autorización, a los llamados de la religión reformada que puedan vivir y cumplir en todas las ciudades y lugares de este reino y nuestros paises de nuestro dominio, sin ser molestados, abusados sexualmente, ni obligados a hacer nada en materia de religión contraria a su conciencia [...]".

d) Pacto/Compromiso del Mayflower ("The Mayflower Compact”, año 1620, en Cabo Cod, por la mancomunidad): "En el nombre de Dios amén. Nosotros los abajo firmantes leales súbditos de nuestro venerado soberano el señor rey Jacobo, por la gracia de Dios rey de Gran Bretaña, Francia e Irlanda, Defensor de la fe. Habiendo emprendido para la gloria de Dios, avance de la religión cristiana y el honor de nuestro rey ypatria, un viajepara establecer la primera colonia en las partes septentrionales de Virginia. Por el presente instrumento, solemne y mutuamente, en presencia de Dios y ante nosotros mismos, pactamos y nos constituimos en un cuerpo politico civil para nuestra mejor organización y preservación, y prosperidad de los fines anteriormente mencionados. En virtud del mismo, para dictar, constituir y establecer, de tiempo en tiempo, todas aquellas justas y equitativas leyes, ordenanzas, actas, constituciones y dignidades que se consideren más adecuadas para el bien de la colonia. A las cuales prometemos toda la debida sumisión y obediencia. En testimonio de lo cual firmamos este documento en el Cabo Cod el once de noviembre, en el reinado de nuestro Rey Jacobo de Inglaterra, Francia e Irlanda, y quincuagésimo cuarto de Escocia. Año del Señor mil seiscientos veinte".

e) Ley de tolerancia ("The Tolerance Act" o "An Act concerning religion” of Maryland, año 1649, en Baltimore, por Lord Baltimore, el Consejo y la Asamblea General de la Provincia): "En vista de que una mancomunidad bien gobernada y cristiana, lo primero que debe ser tomado en seria consideración, y debe ser regulado, es lo referente a la religión y al respecto a Dios [...] queda ordenado por el Honorable Cecilius Señor de Baltimore, y Propietario de esta Provincia, con el consejo y parecer de la Asamble General [...] que en adelante en esta mancomunidad si alguna o algunas personas blasfemaran contra Dios, $o$ le maldijeran, o negaran que nuestro Salvador Jesucristo es Hijo de Dios, o que 
la Santísima Trinidad está formada por el Padre, el Hijo y el Espiritu Santo, o la Divinidad de una de las tres personas de la Trinidad o la unidad de la Divinidad, o pronunciara cualquier discurso, palabras o lenguaje reprobable respecto de la Trinidad, o de cualquiera de las Personas divinas, deberán ser castigados con la pena de muerte y la confiscación o pérdida legal de todas sus tierras, a favor del Lord Propietario y de sus herederos. $Y$ dado también que forzar las conciencias en materia religiosa se ha demostrado frecuentemente como peligroso, en los paises en que esto se ha llevado a cabo, y con el fin de asegurar un gobierno más tranquilo y pacifico en esta mancomunidad, asi como para la mejor conservación de la amistad y el afecto entre sus habitantes, igualmente el Lord Propietario, con el consejo y parecer de la Asamblea General, ordena que en adelante creer en Jesucristo no será incomodada ni molestada o perjudicada de ninguna forma a causa o con respecto a su religión, ni en el libre ejercicio de la misma en el territorio de la mancomunidad, ni obligado de ninguna manera a la creencia o a la práctica de otra religión contra su consentimiento, con tal de que esta persona no sea desleal con el Lord Propietario, ni produzca violencias o conspire contre el gobierno establecido actualmente o en el futuro bajo su autoridad o la de sus herederos; y el intento deliberado de molestar o perturbar intencionadamente, directa o indirectamente, en persona o bienes, a cualquier persona de esta mancomunidad que crea en Jesucristo, a causa de la religión o del ejercicio de ella, contraviniendo asi lo dispuesto en esta Ley y en su sentido verdadero, salvo lo que se dice en la presente, será castigado a pagar, a la persona o personas perjudicadas, el triple del importe de los daños causados, y a pagar ademáspor cada infracción de este tipo una multa de veinte chelines de plata en moneda o su valor equivalente, y si la parte asi ofensora fuera incapaz de indemnizar, o se niega a hacerlo, será castigada severamente mediante flagelación pública y encarcelamiento".

\section{Conclusiones}

En Occidente, mediante la combinación progresiva y programática de su tradición sagrada (judeocristiana) y profana (grecorromana), se ha logrado un juego variopinto de experiencias fluctuantes (de tendencia secularizante) en las relaciones entre el poder, lo sagrado y la libertad ${ }^{14}$. De tal manera se ha logrado el tránsito al Nuevo Régimen, pudiéndose distinguir así entre ideas y creencias, individuo y comunidad, política y religión, Estado e Iglesia, etc. Se insiste en que tal devenir no ha sido lineal ni pacífico, con episodios de avances y retrocesos, incluso con sonadas experiencias fallidas, sin embargo,

${ }^{14}$ Véase: SÁnChez-BAyón, Manual de Sociología jurídica estadounidense (2a edición, Madrid, 2009). 
no se ha cejado -sirviendo cada tropiezo para intentarlo con mayor ahinco-. Es por todo ello que no cabe una narración lineal de la rama jurídica ni de disciplina encargada de su estudio, el Derecho Canónico primero y el Derecho Eclesiástico después, ya que tal proceder supondría incurrir en una falacia natural y argumentativa de intereses subyacentes (como se ha visto en los diversos textos estudiados). El caso es que, el Derecho Canónico y Eclesiástico, no sólo ofrece la versión oficial (entre el poder, lo sagrado y la libertad), tipificada en dada coyuntura, sino que además, su disciplina, resulta un oasis humanista en la formación del jurista, a la vez que permite tender puentes entre Ordenamientos religiosos y civiles. Se insiste en dicha valía, pues hoy más que nunca, dada la crisis que se vive, por el tránsito entre el mundo agónico dominado por el Estado-nación, y el emergente de la globalización, se requiere del Derecho Eclesiástico, disiciplina que sin embargo se halla en peligro de extinción.

El riesgo de extinción del Derecho Eclesiástico -y previamente del Derecho canónico- es imputable a: $i$ ) distorsión/deformación de contenidos y velos cientificistas; $i i)$ supresión de planes de estudios; $i i i)$ ignoramiento de la regulación vigente, donde se tipifíca, etc. Para profundizar en el proceso de extinción del Derecho Eclesiástico se remite a la obra Estudios de cultura político-jurídica (véase la "Bibliografía"). En el presente escrito, en lo que sí se ha incidido, es en la importancia de recuperar los fundamentos iuseclesiasticistas, como guía para solventar buena parte de los problemas y amenazas actuales, de confusión de órdenes, que bien podría derivar en entropía y/o parusía social.

Se espera haber clarificado lo suficiente acerca de la riqueza de acepciones que comporta la denominación Derecho Eclesiástico. Igualmente, se espera haber transmitido las pautas para distinguir entre su Historia, su historiología y su historiografía. Finalmente, también se espera haber contribuido a sentar sólidas bases para el desarrollo del Derecho Eclesiástico, lo que supondría, de un lado, la no extinción de la disciplina y su Ordenamiento, y de otro lado, la continuidad del diálogo entre órdenes y Ordenamientos, fortaleciéndose la sociabilidad -tan en riesgo actualmente, debido al rechazo de instituciones tradicionales, que guiaran en las relaciones sociales-. En definitiva, se espera haber invitado a la reflexión que tanto se requiere en este momento -pese a la primaria descriptiva de textos presentada, pero es que sólo a través de la evidenciación de las fuentes originales resultaba posible desmontar buena parte de las actuales falacias, imposturas e inferencias dominantes-.

Otrosí se hace constar, entrando en particularidades, como es el hecho del incremento de errores de fundamento, debidos en buena medida a la corrupción de las fuentes, por una endogamia en la cita de manuales no científico-académicos, sino propiciadores de velos de confusión (como los 
denunciados aquí). Se espera que este estudio anime al redescubrimiento urgente y necesario de las fuentes originales y la guía pensamiento que ofrecen.

\section{ApÉNDICE BIBLIOGRÁFICO}

Ofrezco una bibliografía selecta sobre los temas tratados en este artículo, que pudiere ser útil al lector interesado:

Ahlstrom, Sydney, A Religious History of the American People (New Haven, Yale University Press, 1972).

Bellah, Robert, Beyond Beliefs (New York, Harper \& Row, 1970).

Bellah, Robert, The Broken Covenant: American Civil Religion in the Time of Trial (Washington, The Seabury Press, 1975).

Dawson, James, America's Way of Church, State, and Society (New York, MacMillan, 1953).

Gallup, George y otros, The People's Religion. American Faith in the 90's (New York, MacMillan, 1989).

GonzÁlez, Marcos - Sánchez-BAyón, Antonio, Derecho Eclesiástico de las Américas (Madrid, Delta, 2009).

GonZÁlez, Marcos - SÁnchez-Bayón, Antonio, RIDE (Madrid, Delta, 2011).

Hudson, William, Religion in America. An Historical Account of the Development of American Religious Life (New York, Charles Scribner's Sons, 1973).

Legler, John, The Two Sovereignties. A Study of the Relationship Between Church and State (Boston, Philosophical Library, 1952).

LipSet, Seymor, Religion and American Values in the First New Nation (New York, Basic Books, 1964).

Malbin, Michael J., Religion and Politics: the Intentions of the Authors of the First Amendment (Washington, American Enterprise Institute, 1978).

Manning, Leonard, The Law of Church-State Relations in a Nutshell (St. Paul, West Publishing Co., 1981).

MeAd, Frank y otros, Handbook of Denominations in the United States (Nashville, Abingdon Press, 1985).

Mecham, John LL., Church and State in Latin America (Chapel Hill, University of North Carolina Press, 1934).

OlmStead, Clifton, History of Religion in the United States (Englewood Cliffs, PrenticeHall, 1960).

Pfeffer, Leo, Church, State and Freedom (Boston, The Beacon Press, 1967).

Pfeffer, Leo, Creeds in Competition: A Creative Force in American Culture (New York, Harper \& Row, 1958).

Reichley, A. James, Religion in American Public Life (Homewood, The Brookings Institution, 1985).

SÁnchez-BAyón, Antonio, Estudios de culturapolitica-jurídica (Madrid, Delta, 2009).

SÁNCHEZ-BAYÓN, Antonio, La Modernidad sin prejuicios. La religión en la vida pública estadounidense (Madrid: Delta, 2008-13), 3 volúmenes.

SÁnchez-BAyón, Antonio, Derecho eclesiástico global (Madrid, UCJC/Delta, 2011). 
SÁNCHEZ-BAYón, Antonio, Estado y religión de acuerdo con los EE.UU. (Saarbrücken, EAE, 2012).

SANDOZ, Ellis, Government of Laws. Political Theory, Religion, and the American Founding (Baton Rouge, Louisiana State University Press, 1970).

SEwARD, Edward, Religion in American Culture. A Sociological Interpretation (New York, The Dorsey Press, 1964).

StARK, Rodney - Glock, Charles, American Piety (Berkeley, University of California Press, 1970).

Stokes, Alson, Church and State in the United States (New York, Harper \& Row., 1950), I-III.

Tuveson, Ernest. Lee, Redeemer Nation. The Idea of America's Millennial Role (Chicago, The University of Chicago Press, 1968).

Tyler, Alice, Freedom's Ferment. Phases of American Social History to 1860 (Minneapolis, The University of Minnesota Press, 1944).

Wood, James y otros (editores), Church and State in Scripture. History and Constitutional Law (Waco, Baylor University Press, 1958).

Zollmann, Carl, American Church Law (St. Paul, West Publishing Co., 1933).

\section{BIBLIOgRAFÍA CITADA}

Polo, José, Derecho y factor religioso (Madrid, Dykinson, 2012).

SÁnchez-BAyón, Antonio, Sistema de Derecho comparado y global (Valencia, Tirant lo Blanch, 2011).

Sánchez-BAyón, Manual de Sociología jurídica estadounidense (2a edición, Madrid, 2009).

VV.AA., Derecho eclesiástico del Estado (Valencia, Tirant lo Blanch, 2012). 